\title{
The Finite in Tune with Infinite
}

Dr. Ku. Richa Shrivastava

Editor Vishwa Jagriti Mission and Life Pathway

PhD, IIT, Roorkee

Bhopal, M.P. India

richashrivastavaiitroorkee@gmail.com

\section{Abstract}

For your betterment choose the best Guru and endeavor to do Satsang in your life that is the preaching of the consecrated saints. If you people will become the disciples to a Guru and grace with your presence at an ashram, you will acquire knowledge from him. Guru accepts all impure intellects as well as enlightens them with knowledge. The major rituals cannot offer what you will possibly gain from saints preaching. Enlighten yourself with sermons of your Guru. Purge your mind with the knowledge which keeps deviating in all directions; treat it with the lullabies of God name. Next, it will get surrendered to God's wishes.

"O, Supreme Being! My heart and soul is not mine, it is yours". Entreat in this style. Psyche sets out around all the matters of the world, where it reaches; it thinks about those matters. Make it God's devotee, and then see the magic. Control your thoughts. Clean and purge your thoughts. Behave abstemiously. If your mind is in control, it could tackle the whole world. A little key could keep the safety of home. In the same way, that key will control your notions that key is the name of almighty. Your guru mantra will safeguard your 
mind similarly, as a small key maintains the house secured. Concentrate your mind in the saviors' name instead of its getting filled with thoughts. Concentrate on your heart energy zone and if possible on your brain energy zone, thereby get showers of blessings from omnipresent. In brain deliberations arise, vacate your brain from all futile deliberations. As plants are planted, water is sprayed, in the same manner, provide knowledge to your brain, as cow dung is supplied to plants, similarly do tapas for your brain. As the plants bestow fruits, your consciousness will exhibit you the God's glance. Implore to God, "Omnipotent! On condition you wish for me to confer something less, it could be power, position, money, and luxuries, but bestow me devotion to the utmost so, I could get your visualization daily".

While you plead those are the sentiments which matter. Words do not matter. You could request almighty in your own utterances. Do not beg which is written in verse. Entreat from your own mind with all your dedication. You will attempt to approach near omniscient. As each and every flower is fresh, correspondingly; endeavor to pray lord from your own compassion where each and every thought should be original. If your attachment is in optimistic direction, it's beneficial. As firm as your belief, so effective is the result. In the existence of a devotee because of devotion transformation takes place. The bloom takes place in life cycle. The miracles happen as a consequence of bhakti, whosoever has taken the name of Supreme Being and all his distress are over. Do not weep in life for what you do not have? The aficionado of Supreme Being thinks in the life span that for sometimes the sufferings take place, and then we are familiar with who our well-wisher is, and who is against us. Thereby, we also come to identify what is bad in life. Whatever God confers every day accept it with contentment. "Please almighty grant us control to forbear all the agony in coming time". Never ever complain he is our best well-wisher who does not leave our companionship in cheerfulness or wretchedness. 
Keywords: Bhakti cult - Devotion towards God, Sadguru - The spiritual Leader, Finite individual, infinite - God.

"O Savior, if I do not have commitment towards you what should I do? Who else is out in this world who loves us other than you?"

The individuals who are dedicated to deity, to whom deity has given two hands, two legs and two eyes, they are not the unfortunate ones. We should pursue Almighty's pathway with all our efforts, we will be capable of distinguish how rich we are? We have very expensive body parts. The great personality who will come to our life who will awaken us, that person expects great reverence from us. He is Sadguru who has revealed all the passageways of bhakti cult. Bow in front of him with care. If you will sob in your entire years for what you do not have, you will by no means seek out the delight of what you have. We forever shed tears for what we do not have; however, we never ever appreciate God in our existence for what he has conferred us. We consent to be his kids and request to him. Express gratitude towards God and subsequently you will find that you do not have the moods of affliction, anxiety, poverty, prosperity, promotion and defeat. You will be contented in all circumstances. That vital energy is all over widespread. God says, "I am not isolated from you, call me with love". When you go to the pathway of bhakti cult you countenance the utmost pain with a smile on your face. His silhouette is benevolent. We can congregate all the conveniences in life but enjoyment, pleasure, sleep; these are all presents of God. With great commitment take his name. "God wheresoever's you keep me, bless me with tranquility, I may summon up your name, grant me the company of great saints. God, please consecrate me; I am not far away from you, call me!"

Great personalities fill up the life with color. They give us inspiration. They raise devotion in us. If someone approaches to your home, do not consider that he has come to ask for alms, so realize that if you will not be the benefactor, at some point you to have to ask for 
alms. The empty bowl which is in his hands, such bowl could be there in your hands too. God does not take much time in exchanging the bowl. We cannot see his hands are charitable although we notice the pockets are filled with money. The true disciples of God worship God a lot and such people are also afraid of his punishments. If you meditate towards supernatural being, it would escort to bhakti, which will light the candle of illumination in your consciousness. For Example, Hanuman ji is the greatest devotee of Lord Rama. When he had free time from looking after the lord Rama, he used to pray him. Lord Rama has been pleased from his devotion and illuminated his consciousness. Similarly, for enlightenment, there are two features of bhakti cult take niyam, choose a lonely place for meditation. Implement selfrestraint and self-control. Leave worldly cravings. Do not accumulate possessions. For instance-Do not make your home, a storehouse for assemble of things.

Do not ask over Almighty for special belongings, inquire omniscient for his bliss. Request omnipotent that I fancy you to take my concern, solicit the supernatural being to forever stay in my heart's temple. Plead for his mercy. On condition you ask for these abstract feelings, everything will enter into your life. Next, your life will become enjoyable.

\section{What you yearn to do Tomorrow, Do it Today}

What you want to do after a short while, do it at present. In seconds the catastrophe may happen, after that how you may possibly do it? Do not leave suddenly today's vocation on tomorrow, your mentality may get modified and perhaps subsequently you may not be capable of work. Tomorrow, this contemplation may not revive you. If you would like to leave an awful habit, abscond it today. Acquire this rigid decision in your psyche. Refrain from a terrible practice for twenty four days and perform an excellent routine for next twenty four days. Like this you probably would be up to leave your bad habit in forty eight days. Imagine about now and aim to do something amazing for your betterment these days.

What has taken place in past, it has gone, 
It will never come back. Wait for that which will come tomorrow.

Do at present whatever you can do for your up-lift.

We have wept a lot in the four walls of our home. Step forward take an action for your betterment.

The past is fabulous, Future is alright,

Whatever is going on we can improve it, through progress is the present.

Future will be bright.

Nevertheless if you turn out to be anxious for what you have to do in future is not right. We have visions in our mind. When there are dreams, we have desires. When there are desires, there is tension in the mind. Breakout stress and execute your mission in best possible manner. Be punctual. The individuals those who best manage the time attain success.

After being successful, almighty consecrates all of us. You will find that those who are firm in their fortitude are most affable to God. We receive blessings from omnipresent, sense supreme being's blessings in all circumstances in all these years; we lack willpower to absorb his blessings. As resulted, we experience pride of our achievements. Pride has a fall, when we fall, thereby, do not be flop as a consequence of your grief. Each and every fall teaches something incredible. The individuals who do not undergo sadness in disappointment issues and uncertain complicatedness, those who are impartial, those, who do not deceive, such hearts are God's temples. The finites are in tune with the infinite that are free of envy and malice. They do not discriminate against one another. Such personalities have fragrant reflection.

In life the fragrance comes from own thoughts. Everyone's welfare is our motto. Always ask from supernatural being whosoever is disheartened; I might facilitate those human beings in their sorrow. Endeavor to win your faults. Do not think that your diseases, debts and enemies are frail. Strive to saunter in the correct path and thus you may attain 
accomplishments. Make an effort to be pure from your heart. When your inner being is chaste, you will listen to divine spirit's voice clearly. Aim to stop over thinking about your afflictions.

After overcoming your sufferings, every day put into practice that you will laugh. Whilst you roll with laughter you turn out to be more cheerful. If you guffaw and hum songs you will not come across difficult times. Seek to titter heartily at least four times in a day. For your fitness, it is essential to express amusement. Though you laugh your spirit is free to envisage deity. Proviso you sit with a smiling person, you will also chuckle. In childhood, we cackled generously, as at those early years, we do not have any apprehension. God spells his charm when you chuckle. If you are joyful in present you will also be contented in your near future.

World is very depressive defeat it. Until you subsist overpower intricacies with all your efforts. When knowledge reaches foremost you overcome excessive affections, because of affections we are attached in this world. Even if someone special cheats us, even then we memorize that friendly being. In this way, we are lost in despair of fondness. Whilst you put down friendliness, you become self-restraint. Self-control comes in years. Currently, we necessitate arising positively. Follow decency and kindness wholeheartedly. Seek to suppose about all infamy and defame which the public will name you for your evil tasks. If you be inclined to do well, do not feel any hesitation. Observe, in the dusk, what all good deeds you have performed, perceive what bad deeds you have done. Request almighty that, "I could abscond all my awful habits; grant me power to do so". Aspire to enhance your present.

The Moments of Satsang

A boat has been created by your sadguru of Satsang, sit in it and get across the worldly river. The moments of Satsang are salient in life for all the human beings those are finite. From the business of life extract for a while for satsang, dedicate your time in the 
deliberations of God i.e. infinite. Parmatma is not secluded from us. The infinite is within us. Devoid of Satsang the finite those are humans get deflected away from the exact path and this is the reason for their fears. Approvals of divine connect humans to devotion. We show our feelings to God in our own words that are prayers. Appeals in masses have a great effect. That place is purged with good feelings of the devotee where we remember God. Until when we are physically fit, we may get accomplished our classy dreams. In case, we have the great yearning to get tuned in to unknown, unless whilst we have time, get alert, and seeks to realize the differentiation between body and soul. Body is the medium, through which all can value the soul and its way. In the last part of our existence, we will suffer plus we will not be capable of succeeding the loss which occurred in our life, then we will think that I have passed my valuable time in worthless things. Therefore, attend satsang so as to inspire yourself to the mottos of great saints. On condition you are polite and pure, you try again and again, and you will reach up to Parmatma. To fulfill your desires intervene in the daydreaming of worldly affairs. Regularly, continue the chant of Mahamrityunjay Mantra in combination with Gayatri mantra, so that your worldly desires may well get fulfiled very often and then:

\section{Mahamrityunjay Mantra}

From The Rigveda (RV 7.59.12)

Om Try-Ambakam Yajaamahe

Sugandhim Pusstti-Vardhanam

Urvaarukam-Iva Bandhanaan

Mrtyor-Mukssiiya Maa-[A]mrtaat || and

\section{$\underline{\text { Gayatri mantra }}$}

From The Yajur Veda 
Om Bhuur-Bhuvah Svah

Tat-Savitur-Varennyam

Bhargo Devasya Dhiimahi

Dhiyo Yo Nah Pracodayaat \|

Believe in divine, he never disguises you. To gain Supreme Being's association we all necessitate a guru. Correct Guru is a true guide. He never falsifies all of us. Step in the path which is told by your chosen Guru as well as control yourself. As you're within the need arises more and more of worldly desires, your mind gets worried. If you want to abstain yourself exercise strong will power that you will be correct.

Where there is a will, there is a way. For all the works to be done you need strength of mind, with that you can complete all kinds of work. When you have strong willpower what was not intended to happen that will also have effect. The world of imagination could be very beautiful. To get conformed your dreams you also have to intone guru mantra. The realism of this earth which is observed by vision is that there is nothing which you obtain and it is with you forever and ever. Parmatma is one thing which will never diminish. World is lethal. Aspire to comprehend this mortal world. Then, you will realize the immortal Almighty. To take birth and die is the procedure of body. Kala is there to catch and to fetch each and everyone. We all came and we all will fell asleep, whether he is a king or a criminal. One is sited on the throne and the other is tied with shackles.

When great personalities leave this world, they leave their greatness of performance as good deeds behind them. Lord's shadow is filled with bliss and world's shadow sheds sadness. Always request from Supreme Being, that "Whether you keep me in a palace or in a hut, but do not let me be away from you". Formulate your home into a holy place, and then pray to supernatural being. "Oh Omnipresent I may be drawn in worldly pleasures. Almighty permit me to cross this worldly sea in your boat by you. I am at your feet, do mercy on me; 
give me an idea about the correct path. God give me bhakti i.e. devotion, give me power and give me redemption". Those heads that are bowed in Guru's and God's feet, such individuals are capable of hold above their heads and subsist respectfully on this earth. Aspire to feel the presence of the Guru and the God in each and every pious moment. The eyes which glance at deity, those are the thankful eyes. The ears which pay attention to idol's prominence, those ears are obliged. The tongue which converses day and night about almighty, that tongue is grateful. Daily follow satsang and uplift your life.

"May my voice be used to take the name of God", so for this sit with great saints. The company of great saint means as an adolescent learns in his parents company their language, their sanskar. In the same manner, as you assemble in Guru's company, you gain knowledge concerning the supernatural being through his preaching's. When you spent precious time at satsang, you obtain the ananda or pleasure, so attach yourself with satsang. Some people indulge in sex relations with more than one person, enjoy intoxicants like liquor, smoking and consume non - vegetarian food, thereby forget their purpose of existence. We have revived into this world to purify our souls. If you overlook the worldly contentment and remember only Almighty then omnipresent will be present in front of you as a shining light or a glaze of sun. This time cannot be compared with other time. How so much is the greed, lust and intoxication do not sacrifice the time for God's meditation in such materialism. Suppose today, your mind is in complete devotion and you take the pledge for daily simran, then your mentality will be devoted in holy bliss. When there is austerity, there is devotion towards the Guru and the God, Satang bestows us the way towards life. Men' conducts are the best result orientation of his deliberations. Daily practice of niyam and regularly listening to Satsang formulates our thoughts pure. Do not wish for the possessions which deviates us from the path of loyalty. Do not invest even a single second of our being in useless chatters. The occasion that has gone, that has been the past, protect the upcoming time. Do Earthly deeds 
and keep imploring the Lord. Dedicate your every moment to the Lord Krishna. Increase the chant of God's mantra, and amplify your devotional wealth. Aim to surprise the Lord by doing excellent deeds.

The exact time to go towards satsang is adulthood. While we will be old, will we offer a rotten flower to divinity? In our elderly age, when we would not be capable of listening to satsang, when eyes might not know how to see God's grace, legs cannot be fit for walking, and then will we go to idol worship? Subsequently, we will be repentant that we have conceded our being without prayers and at present the accurate time for entreat has already been spent.

Good attitude, better discipline, best wishes from your heart, loyalty towards God, knowledge of righteousness, abstention from intoxication, adherence of high moral values and fulfilling duties is like drinking drink of immortality and you get this drink from Satsang. The human beings, who are disgusted of others, feel envious of everyone's progress and fight with others like animals are evil spirits. Human body is not for gorge and glutton. Neither human life is for luxuries or for all sorts of mature pleasures and carnal enjoyments. Human life is for to do good and welfare of all living beings for reason that no one could identify when the Kaal will arrive and take away life. Once, the death day appears to everyone, on this day all will fall asleep forever, you will not awake and this Earthly inhabitants will aim to break up your sleep.

This entire world will be filled with colors of life, even after our death. God has created this world with great splendor and glamour. Mirror does not change. In the same way people of this world keep changing: they take birth and die. Our bhakti could arise only when Vairagya takes place. In this world we all take birth to meet altogether and then, to get apart, end of every life is death; so therefore practice all good virtues. Every day help out people in addition to that do self - study, the awareness which you will accomplish by interpretation of 
pious books is a varied sort of knowledge than whatever information you have experienced in your existence. If in bhakti we do not have comprehension subsequently our conviction will turn into blind - faith. The correct awareness could be achieved by analysis of sacred manuscripts and attending as well as listening to spiritual discourses of correct Gurus. The works in your life will by no means come to an end. Reside in this world and do not get struck up in this humankind. Aspire to believe the greatest unity that is God to detach you from this planet. We all approach at this juncture with closed fists and fortune. When we depart, we leave the whole lot and we have our palms open. The human race will not come in your hand over or your command. Do not get to a great extent fascinated towards the humanity we will have to leave all. Whatsoever is globe's attraction, it changes into distraction. Implore to almighty, "Send me to the Lok where there is immortality and Ananda." Keep patience to face perseverance. Only this is the art of living, there is importance in spiritual discourses which cannot be displayed by words, Guru is the remedy of many problems, guru has given the way how to live life, he is the example for how to effort for very tough targets to rejuvenate life, the seeds of Guru's knowledge, one day turns into a flower. No one is as good as Sadguru; no religious aspect is like Gita. There is no object that could be compared with God. No way is the way like love of God and blessings of Guru. 


\section{Works Cited}

“Gayatri Mantra - In Sanskrit with Meaning”, Green Message 2019. Web 17 December 2019. Web 17 December 2019.

https://greenmesg.org/stotras/gayatri/gayatri_mantra.php

“Maha Mrityunjaya Mantra - In Sanskrit with Meaning”, Green Message 2019. Web 17 December 2019. Web 17 December 2019. https://greenmesg.org/stotras/shiva/mahamrityunjaya_mantra.php

"Ramayan Story: Hanuman in Search of Rama's Ring". Bhagavatam - Katha, 2019. Web 16 December 2019. http://www.bhagavatam-katha.com/ramayana-story-hanuman-in-search-of-ramasring/

Swami, Prabhipada, A. C. Bhaktivedanta. Bhagvad Gita as it is, Watford: ISKON Reader Services, 2010. Print. 